\title{
40
}

\section{A Positive Freedom of Public Speech? Australian Media Law Reform and Freedom of Political Communication}

\author{
Andrew T Kenyon ${ }^{1}$
}

Proposals to reform Australian media law arise frequently; recent examples have included a merger of public broadcasting organisations and changing legislative ownership limits for commercial media. What might such proposals have to do with the idea of free speech, in particular as it relates to public discourse? Here I explore an approach to free speech recognising positive or structural aspects of the freedom as well as negative or liberty aspects. In short, free speech entails both diversity of voices and absence of censorship, not merely the latter. The outline presented here suggests changes to Australian constitutional interpretation could be warranted, or at least their exploration deserves attention, even if such changes appear unlikely soon.

There are also implications for legislative and executive action - they could take into account positive and structural aspects of free speech which, to date, are rarely acknowledged. That sort of change could more plausibly

1 Professor, and Joint-Director, Centre for Media and Communications Law, University of Melbourne. 
happen in the short term, although it also faces challenges. In particular, parliament and executive appear unlikely to achieve adequate protection for free speech if the matter is left entirely open to their choice.

\section{Some Introductory Caveats}

My interest here lies in public speech or public discourse within democratic contexts. This focus seeks to separate free speech as a constitutive element of democratic government from free speech as a liberal or human right. As with Eric Heinze's recent analysis in the different context of hate speech, ${ }^{2}$ my aim is not to suggest that democracy supplies a complete approach to free speech; rather, claims to be democratic carry particular necessary implications for free speech. Also by way of caveat, the positivenegative terminology is not meant to suggest that the state is ever absent in terms of free speech or state-media relations. The government is always involved; as Victor Pickard states, 'the real question is how the government should be involved'.

Clearly, this approach to free speech involves contested terms, 'democracy' in particular. But the essentially contested nature of democracy offers some support to the approach outlined here. I will take democracy to contain a claim to political self-rule in one form or another. The repeated failure of democracies in practice - the 'internal exclusions and subordinations' of 'class ... gender, sexuality, race, religion, ethnicity, and global origin' does not remove the idea's ambition and appeal. Along with its failures, democracy has also carried the language and promise of inclusive and shared political equality, freedom, and popular sovereignty'. ${ }^{4}$ The point for present purposes is that forms of self-rule imply a particular approach to free speech and, I would suggest, democratic constitutional arrangements also presuppose it. This is reinforced by the fact that democracies may be reformed. That possibility for reform can be itself seen to require diverse public speech: 'public discourse is the constitution of the constitution'.5

2 Eric Heinze, Hate Speech and Democratic Citizenship (Oxford University Press, 2016).

3 Victor Pickard, 'Toward a People's Internet: The Fight for Positive Freedoms in an Age of Corporate Libertarianism' in Maria Edström, Andrew T Kenyon and Eva-Maria Svensson (eds), Blurring the Lines: Market-driven and Democracy-driven Freedom of Expression (Nordicom, 2016) 61.

4 Wendy Brown, Undoing the Demos: Neoliberalism's Stealth Revolution (MIT Press, 2015) 44.

5 Heinze, above n 2, 6 (emphasis in original). 
It is worth noting, however, that completely elite forms of government are excluded from this approach; such forms of government do not require free public speech. But where a democratic polity claims to be not only about elite rule, where it claims to temper democracy's tendencies towards elite domination, then wider aspects of free speech are implicated.

\section{Positive Freedom of Public Speech}

Draconian state restrictions on speech attest to the importance of negative free speech. But to suggest that speech is free whenever the state does not directly restrict it obscures the state's role in public communication. Free speech also has positive aspects. In considering those, there are many intellectual sources that could be drawn on, ${ }^{6}$ including:

- legal scholarship about free speech (using ideas broadly consistent with those presented here);

- writing from media studies and media policy, where recent work offers clear engagement with the idea of positive freedom;

- writing about positive liberty or positive freedom, often in political philosophy, although that work has surprisingly little to say directly about free speech or mediated speech;

- human rights law scholarship about positive rights, which again tends to focus on other matters than speech; and

- some formal law, including constitutional courts in France, Germany and other parts of Europe (and perhaps parliamentary processes and legislation in Northern Europe). The legal examples often engage with specific aspects of positive free speech, rather than its wider implications. The German Federal Constitutional Court's analysis of free speech and broadcasting is a strong example of that, which is considered further below.

6 See, for example, law and media studies literature discussed in Andrew T Kenyon, 'Assuming Free Speech' (2014) 77 Modern Law Review 379; Carol C Gould, Rethinking Democracy: Freedom and Social Cooperation in Politics, Economy, and Society (Cambridge University Press, 1988); Sandra Fredman, Human Rights Transformed: Positive Rights and Positive Duties (Oxford University Press, 2008). 
Thus while the concept of positive free speech might appear foreign to Australian law, it is not at all unknown as an idea. Aspects of it can be seen in a host of writing across a range of disciplines, although it has tended to be an idea without powerful friends. Given limited space here, I simply use two short quotes to explore the idea.

Free speech might be considered as a bare liberty that requires only the absence of government restriction. It subjects government action to judicial scrutiny where that action would restrict speech. But free speech need not be seen only in such negative terms. Applied philosopher Onora O'Neill observes that the apparent absence of government action does not leave public speech free from influence:

[L]aissez-faire communications policies merely assign the regulation of communication to nonstate powers. They secure a particular configuration of freedom of expression, which may leave some unable to find their voices and does not guarantee the expression of diverse views. ${ }^{7}$

Similar ideas have been raised by many commentators, but I note the O'Neill example because she then suggests points of relevance here. In short, she argues that, in a democratic context, there should be an aim to enable sustained diverse public communication, while recognising the impossibility of complete non-interference with communication.

Enabling sustained diverse public speech in a democratic context might be thought to lie 'beyond' free speech. But not necessarily, as Judith Lichtenberg explains. The multiple rationales commonly seen to underlie free speech can be grouped into two broad goals:

These commitments can be described in terms of two basic principles. The first we may call the noninterference or no censorship principle: One should not be prevented from thinking, speaking, reading, writing, or listening as one sees fit. The other I call the multiplicity of voices principle: The purposes of freedom of speech are realized when expression and diversity of expression flourish. ${ }^{8}$

7 Onora O'Neill, 'Practices of Toleration' in Judith Lichtenberg (ed), Democracy and the Mass Media: A Collection of Essays (Cambridge University Press, 1990) 155, 178.

8 Judith Lichtenberg, 'Foundations and Limits of Freedom of the Press' in Lichtenberg (ed), Democracy and the Mass Media: A Collection of Essays (Cambridge University Press, 1990) 102, 107 (emphasis in original). 
She maintains that diverse, multiple voices are needed for free speech interests to be met. More than speech itself, it is debate and diversity of ideas that are required. And such debate and diversity cannot be assumed to exist in market-based mass media; theory and practice suggest they require support beyond markets. ${ }^{9}$

\section{What Role for Courts?}

How might positive aspects of free speech be considered in law? The German Federal Constitutional Court offers a developed example of judgments doing just this. (Although operating within a code-based legal system, the Constitutional Court's decisions have the weight of precedent, binding all actors except itself.) In decisions from 1961 to 2014 the Constitutional Court has set out detailed requirements about television broadcasting, drawing on the free speech protection in Art 5 of the Basic Law and its protection for broadcasting freedom. ${ }^{10}$ A contemporary translation of Art 5 reads:

(1) Everyone has the right freely to express and disseminate their opinions orally, in writing or visually and to obtain information from generally accessible sources without hindrance. Freedom of the press and freedom of reporting through audiovisual media shall be guaranteed. There shall be no censorship. ${ }^{11}$

The provision sits within particular constitutional traditions, and the decisions' merits are subject to ongoing domestic debate. ${ }^{12}$ My primary interest here, however, lies in particular ideas about free speech seen in the decisions, including: free speech's positive aspects; the broad range of media content covered; the constitutionality of a dual broadcasting system; funding public broadcasting; internal pluralism within public broadcasters; what can be called a 'precautionary' approach; and the contemporary media environment. Here, I mention a little more about

9 See, for example, Andrew T Kenyon, 'Assuming Free Speech' (2014) 77 Modern Law Review 379.

10 A useful entry point is Donald P Kommers and Russell A Miller, The Constitutional Jurisprudence of the Federal Republic of Germany (Duke University Press, $3^{\text {rd }}$ edn, 2012).

11 See, for example, Christian Potschka, Towards a Market in Broadcasting: Communications Policy in the UK and Germany (Palgrave Macmillan, 2012) 161 (emphasis added).

12 See, for example, Bernd Grzeszick, 'The "Serving" Freedom to Broadcast: Subjective versus Objective Dimensions of a Fundamental Right' in Hermann Pünder and Christian Waldhoff (eds), Debates in German Public Law (Hart, 2014) 75, 85. 
four of these areas. Overall, they illustrate the power of the idea that free speech requires efforts be made to provide comprehensive, universally available and diverse information.

\section{A. Free speech has positive aspects}

Clearly, free speech is not merely a negative liberty for the Constitutional Court. Article 5's purpose of individual and public opinion formation requires state action; it cannot be met merely by a negative duty. Instead, 'a positive order is necessary, which ensures ... the variety of existing opinion is expressed ... as widely and completely as possible. ${ }^{13}$ In this approach to free speech, broadcasting freedom is a state of affairs in which diversity in content is sought along with freedom from state and market control.

In the German context, constitutional rights establish objective principles as well as subjective protections for individuals. ${ }^{14}$ The state clearly has a 'protective function'. ${ }^{15}$ While acknowledging the German context and history, here I want to flag that a similar result may be reached for free speech rights in other constitutional systems due to the role of public communication within a democratic constitutional order.

\section{B. The freedom is broad}

Article 5 guarantees a broad freedom. While referring explicitly to freedom of reporting, the freedom is not limited to reporting. It serves the wide free speech interests protected by Art 5 as a whole - free individual and public opinion formation - which means it encompasses entertainment content as well as news and commentary. Broadcasting has the constitutional function of providing information in the greatest possible breadth and completeness' because 'opinion formation comes about not only in news broadcasts, political commentaries or series on problems of the past, present and future, but also in audio and TV dramas, musical presentations or entertainment broadcasts'. ${ }^{16}$ In addition, the requirement is not for 'a minimum provision to which public broadcasting is confined

13 BVerfGE 57, 295 (Third broadcasting case).

14 See, for example, Werner Heun, The Constitution of Germany: A Contextual Analysis (Hart, 2011) $198-200$.

15 See, for example, Dieter Grimm, 'The Protective Function of the State' in Georg Nolte (ed), European and US Constitutionalism (Cambridge University Press, 2005) 137.

16 BVerfGE 73, 118 (1986) (Fourth/Lower Saxony broadcasting case). 
or could be reduced'. ${ }^{17}$ It is for a comprehensive service, available to the entire population, containing substantial diversity of opinion. ${ }^{18}$ That is the constitutional mandate of public broadcasting.

\section{A dual broadcasting system}

The above requirements have led the Constitutional Court to hold that a dual system of public and commercial broadcasting can meet the constitutional requirements, but it is a system in which public broadcasting is primary. Commercial broadcasting has been held constitutionally permissible only where public broadcasting is able to meet the Basic Law's mandate for opinion formation. ${ }^{19}$ While that could theoretically change if commercial broadcasting by itself met the constitutional requirements, there is no sign of that in the judicial analysis to date.

\section{Speech requires a 'precautionary approach'}

The importance of free speech means the Constitutional Court takes what can be called a 'precautionary' approach in seeking to lessen commercial and political pressures on public broadcasting. The quasi-foundational role for speech is seen even in Germany where the right to dignity under Art 1 of the Basic Law takes precedence over, and influences the interpretation of, all other constitutional rights. In its classic Lüth decision the Constitutional Court stated:

The basic right of freedom of opinion is ... absolutely basic to a liberaldemocratic constitutional order because it alone makes possible the constant intellectual exchange and contest among opinions that form the lifeblood of such an order; it is 'the matrix, the indispensable condition of nearly every other form of freedom'. ${ }^{20}$

The quoted words ending this extract come from US Supreme Court Justice Benjamin Cardozo. ${ }^{21}$ Their use underlines the German court's view that the 'primacy' of speech is inherent in any democratic constitutional order. And the court is alive to possible concentration of power over public opinion. Caution against such influence is warranted because 'when

17 BVerfGE 74, 297 (1987) (Fifth/Baden-Württemberg broadcasting case).

18 BVerfGE 83, 238 (1991) (Sixth/North Rhine-Westphalia broadcasting case).

19 BVerfGE 90, 60 (1994) (Eighth/Cable Penny broadcasting case).

20 BVerfGE 7, 198 (Lüth case).

21 Palko v Connecticut, 302 US 319, 327 (1937). 
emerging developments prove to be faulty, they can only be rescinded - if at all - to a certain degree and only with considerable difficulty. ${ }^{22}$ That is, speech requires 'prior' protection - protection prior to the institutional political process. The Constitutional Court has continued to apply this reasoning, maintaining that 'precautions for the protection of journalistic diversity' are necessary. ${ }^{23}$ There is nothing about the idea that is limited to the German context. And it is worth emphasising that the need for journalistic diversity is not resolved by the internet: the Constitutional Court has continued its approach as recently as 2014, despite the dramatically different context for public communication compared with its first broadcasting decision in the early 1960s.

A point of general interest from this precautionary aspect of the German approach is that neither executive nor legislature can be left to deal with broadcasting merely as a matter of policy entirely separate from free speech requirements. The free speech issues at stake mean the Constitutional Court sets out requirements that the legislature must meet; requirements which, in turn, restrict the executive's room for action. The legislature cannot, for example, limit public broadcasting to its current technological basis. ${ }^{24}$ That would breach the requirements of Art 5. The German court acts because it is implausible - and unconstitutional - to leave the structure or architecture of public speech solely to legislative and executive action. If structures affecting public communication also influence political processes - a situation which appears undeniable - there is a sense in which some of the architecture of public speech must be prior to public debate and decisions by politicians.

This suggests an approach in which a democratic commitment to free speech implies media of different institutional forms, internal organisation and economic base containing speech of diverse content and style, aimed at different ends, creating different and only partially overlapping publics, and seeking to influence (among other things) political decisions. Public debate and parliamentary or executive action could reshape this style of architecture of public speech to some degree, but the changes could not go beyond the requirements of free speech in terms of non-censorship and diversity.

22 BVerfGE 57, 295 (Third case).

23 Fourteenth/ZDF Treaty case (2014) [36].

24 For example, BVerfGE 83, 238 (1991) (Sixth/North Rhine-Westphalia case); BVerfGE 119, 181 (2007) (Twelfth broadcasting case). 
The claim being made is not that the German situation fulfils such an approach to free speech, but that it is an example which suggests ways in which a formally democratic system could go some way towards that goal - and go further than is commonly imagined in Australia.

\section{Australian Implications}

Free speech in Australia includes a freedom of political communication that is implied in the Constitution. It is said to secure 'what is necessary for the effective operation' of the constitutional system of representative and responsible government. ${ }^{25}$ The aim is to give freedom of choice to electors. The overall aim sounds like a plausible vision for democratic free speech: a free and informed choice for voters. Within the realm of political speech, the concept does not appear to be far removed from free speech serving individual and collective opinion formation, as it is said to do under Germany's Basic Law. Beyond that broad similarity, Australia's freedom is said not to be an individual right. Instead it is a limitation on legislative power ${ }^{26}$ (and a freedom to which the common law must comply). The first step is understandable, at least in that free speech is not only an individual right (when free speech is understood in the terminology of rights at all). Free speech has structural implications; it is not (only) an individual right. But the second step need not follow: free speech need not only be a limitation on legislative power. In Australia, that has been stated more than it has been explained. And the particular reasons that support judicial action, as seen, for example, in the German decisions, have not been addressed. ${ }^{27}$

The Australian approach may well follow from old ideas that freedoms are residual in Australian law, but more could be considered in relation to this particular freedom. In stating that free speech is not an individual right, it appears that the High Court wanted to distinguish freedom of political communication from the US First Amendment. But it may well be that the advocates appearing before it have not provided sufficient examples beyond the US to allow all relevant matters to be considered in terms of

25 Lange v Australian Broadcasting Corporation (1997) 189 CLR 520.

26 See, for example, McClure v Australian Electoral Commission (1999) 163 ALR 734.

27 Even so there are Australian decisions that would be quite consistent with positive free speech: for example, restrictions on political speech that aim to support diversity overall could be upheld as constitutional, as stated from the beginning in Australian Capital Television v Commonwealth (1992) 177 CLR 106. 
approaches that differ from the US one. That may not change in the short term, in part given the issues of standing and the types of disputes that may come before the High Court. But that situation remains a failing of Australian free speech, in terms of the diversity of speech required by democratic government.

Beyond courts, there are also implications for media policy, such as proposals about the structure or funding of public media or ownership limits for commercial media. Those matters raise positive aspects of free speech, as do issues of appointments to public media boards, statutory missions of media organisations of all types, and so forth. Within the Australian legal system these matters have been left, to date, to parliaments and executives, and to public debate after legislative and executive choices have been made relevant to the structures of public speech. The German decisions suggest why the communicative requirements of democracy may be poorly addressed under such an approach. But they also suggest that debate over Australian legislative and executive action could be made explicitly in free speech terms, and their implications support such debate being pursued in those terms. Matters such as the existence and funding of public media and commercial media ownership limits raise questions of free speech that are central to the idea of Australia having a democratic form of government. 
This text is taken from New Directions for Law in Australia: Essays in Contemporary Law Reform, edited by Ron Levy, Molly O’Brien, Simon Rice, Pauline Ridge and Margaret Thornton, published 2017 by ANU Press, The Australian National University, Canberra, Australia. 